\title{
消化管内における医用機器挿入特性の測定 \\ Experimental study of medical device in an intestine
}

\author{
$\bigcirc$ 世本 敏高（京大） 准 臀仲 潔（京大） \\ 正 池内 健（京大）
Toshitaka SEMOTO, Kiyoshi YOSHINAKA, Ken IKEUCHI \\ Institute for Frontier Medical Science Kyoto University \\ Shogoin 53, Kawahara-cho, Sakyo-ku, Kyoto
}

\begin{abstract}
This paper describes a new low invasive method to drive a medical device with a spiral-ribbed impeller, which converts rotation to axial motion hydro dynamically using mucus. We measured the thrust force and total friction during the propulsion of the device as the differences of the curvature of an organic tube. As a result, both the total friction and the thrust force increased as the reduction of radius of the curvature. However, the thrust force was larger than the total friction. The reason for this, we think, was the reduction of the thickness of the fluid film between an organic wall and a spiral-ribbed impeller. In addition, the thrust force increased largely in increasing the rotation velocity of the ribbed impeller.
\end{abstract}

Key words: medical device, medical robot, intestine, impeller

1,はじめに

現在, 低侵蹎な診断治療方法として, 内視鏡やカテー テルがよく使われている. しかし，内視鏡やカテーテル のように管後方から押すことによって，曲がりくねった 経路を経て体内の深部に誘導するのは困難である。そこ で我々は特に推進機構に着目し, 生体を損傷しない推進 機構を有した機器の開発に取り組んできた(1)(2). 現段 階で我々が考案しているのは，先端に回転機構を備えた 内視鏡や，回転機構自体を有した小型推進機器である。 これまでの研究で, 機器が移動する際に生じる抵抗力を コントロールことが重要であることが分かった．しかし 前回までの研究では, 機器が直線状の消化管内を推進す るという条件のみであった。無論, 実際の消化管は複雑 に屈曲しており，さきの条件では不十分である，そこで 今回我々は, 消化管の曲率半径を変化させて, 機器に生 じる推進抵抗力の相違を計測したので報告する.機器に
は以前開発した流体潤滑を応用した回転によるスパイ ラルリブ型(2)を用いた。

\section{2 , 実験方法} 実験装置概略図を図 1 に示す.

本実験では，実際の消化管を体外モデルで実現するための予 備実験としてビニル管を用いた. 使用したビニル管は内径 $9 \mathrm{~mm}$, 厚み $2 \mathrm{~mm}$ である.ビニル管はアクリル板上に固定されており， 曲率半径に関しては $\mathrm{R}=100 \mathrm{~mm}, 200 \mathrm{~mm}, 300 \mathrm{~mm}$ 及び, 直線で ある. ビニル管の挿入口付近の中心軸とインペラ一の中心軸が 一致するように，ビニル管の先端 $50 \mathrm{~mm}$ を直線状にした. ビニル管の内部には，インペラ一とビニル管の壁面を非接触 に保つため, 粘液を使用した. 使用した粘液はシリコンオイル で, 粘度 $10 \mathrm{~Pa} \cdot \mathrm{S}$ である.

使用したインペラ一は, 直径 $8 \mathrm{~mm}$, 軸方向長さ $5 \mathrm{~mm}$, リブ 高さ $0.6 \mathrm{~mm}$, リブ幅 $0.4 \mathrm{~mm}$ で, 周方向ピッチが 40 度, 傾き 
が 45 度でステンレス製のものである. インペラーは超弾性ワ イヤーを介して動力源の直流のモーターに結合されている.

モーターは, リニアベアリングに固定されており, 回転軸に は，トルクを增幅するための堿速ギアを取り付けている. 駆動 には直流電源を用い，モーターの回転数は $30 \mathrm{rpm}, 60 \mathrm{rpm}$, 90rpm，及び非回転である.

機器に生じる力の計測にはロードセルを用いた．ロードセル は, リニアスライダーのシャフトに固定されており，センサー 部はモーターに結合されている. 本実験でのリニアスライダー の移動速度は $1 \mathrm{~mm} / \mathrm{sec}$ である.

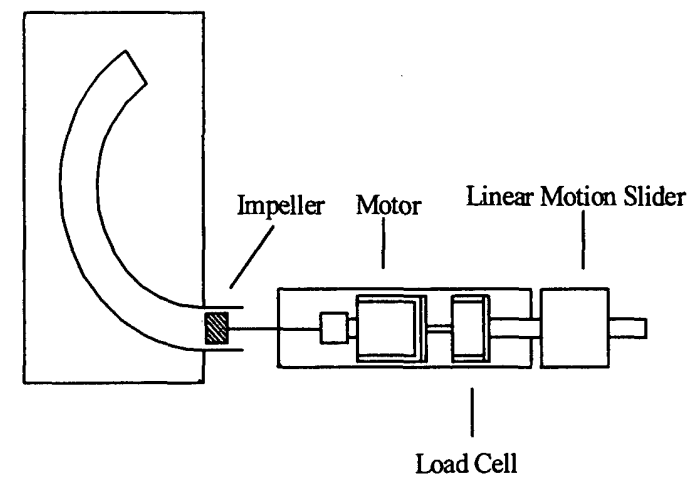

Fig.1 Experimental apparatus

\section{3，結果及び考察}

図 2 にインペラー非回転時の機器に生じる挿入抵抗力を示す. 挿入抵抗力は，管の曲率半径の減少に伴い顕著に増加した. 消 化管の曲率半径 $\mathrm{R}=100 \mathrm{~mm}$ での挿入抵抗力は, 消化管を直線状 と仮定した従来の場合に比べ, 約 4 倍に増加した.

図3にインペラーを30 rpm で回転させたときの挿入抵抗力を 示す. 曲率半径 $\mathrm{R}=100 \mathrm{~mm}$ での挿入抵抗力は, インペラー非回 転時と比較するとおよそ70\%减少した. 直線状, 及び各曲率半 径, いずれの場合においても, 推進抵抗力が顕著に減少してい る.

図4にインペラーの回転数を変化させたときの機器の推進力 を示す. 各曲率半径において, インペラーの回転数の増加に伴 い推進力は增加したが, 回転数が 60rpm と 90rpm では大きな差 はみられなかった，これは，回転数の増加に伴いインペラーと 粘液間にキャビテーションが発生したためであると考えられる. また, 管の曲率半径の減少に伴い, 推進力が増加した. この原 因としては，管の曲率半径の減少に伴い，インペラーに対する 超弾性ワイヤーのたわみによる反力が大きくなり, 結果として
粘液を介した状態での管壁面とインペラーとのすき間距離が小 さくなったためであると思われる.

今後は，実際の消化管を体外モデルで実現し，実験を行う予 定である.

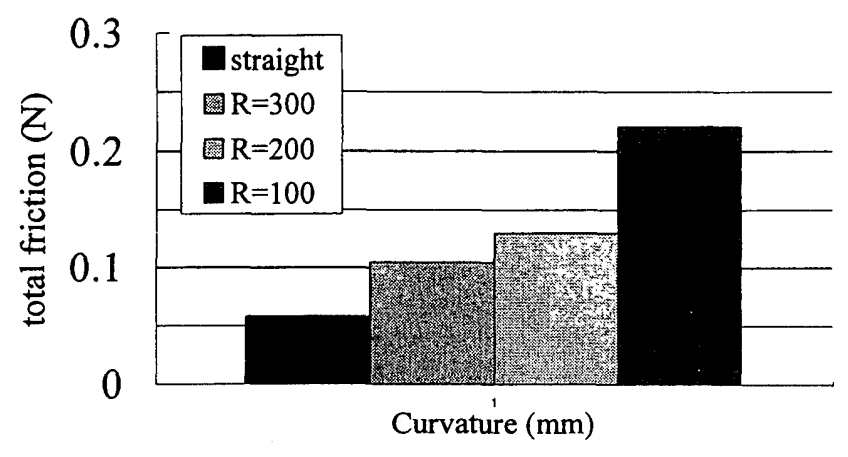

Fig.2 Curvature vs. Total friction (0rpm)

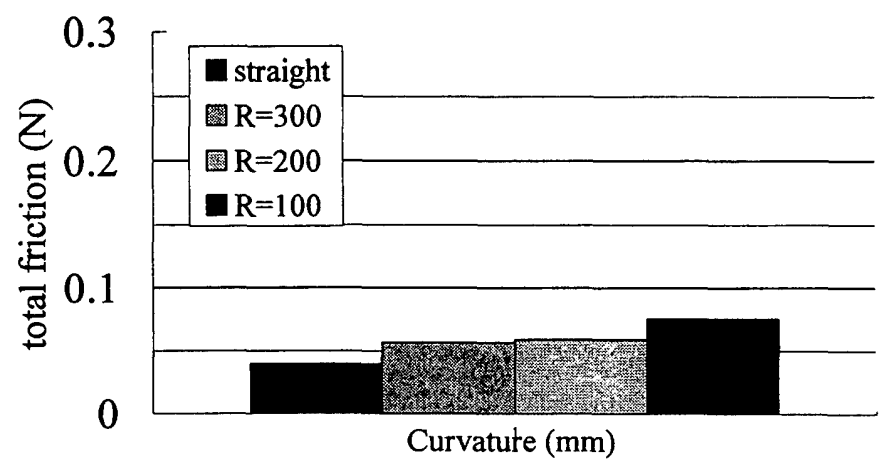

Fig.3 Curvature vs. Total friction (30rpm)

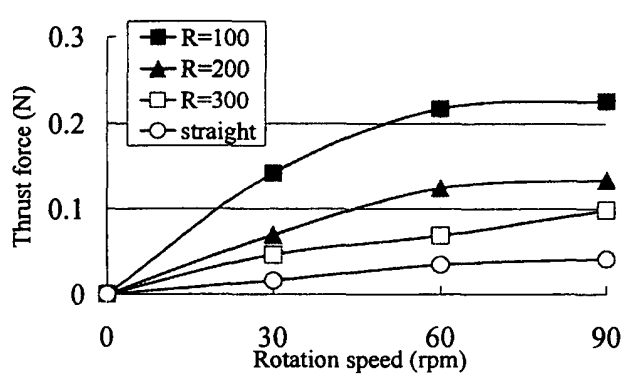

Fig.4 Rotation speed vs. Total friction

参考文献

（1）池内 健, 臀仲 潔 ほか：摩擦制御を利用した推進 機構, 第 11 回バイオエンジニアリング講演会, pp320-321(1999) 